\title{
Analysis of Acceptance Levels on Lunch Menu Among Students at SD Islam Tompokersan Lumajang
}

\author{
Budi Wibowotomo ${ }^{1, *}$, Issutarti ${ }^{2}$, Ria Nadia Avizena ${ }^{3}$ \\ 1,2,3 Department of Industrial Technology, Faculty of Engineering, Universitas Negeri Malang, Indonesia \\ *Corresponding author, E-mail: budi.wibowotomo.ft@um.ac.id
}

\begin{abstract}
. food due to flatness with a less varied menu.

Keywords: lunch menu, boredom, acceptance level

\section{INTRODUCTION}

Student learning activities that lasted until late afternoon causing students feel weak and hungry when learning activities. This students condition when doing activities is probably due to the lack of nutrition. Parents of students who are mostly in working time and can not prepare lunches well, make students go to the canteens and food stall outside the school. Type of foods choosen by children is not correspond with nutritional requirement of children and they prefer more to pleasure food than that healthy foods and their body needs. To anticipate this, the school organized a lunch for the students. Objective of the eating in schools to improve the nutrition of children who do not have breakfast and do not bring lunch to school.
\end{abstract}

The purpose of this study was to analyze the acceptance levels of lunch menu among students at SD Islam Tompokersan Lumajang include acceptance to the color, aroma, taste the food, the level of boredom and consumption levels lunch menu. Research design is used a descriptive quantitative research with cross sectional method. The data was collected by using analytical observation, interviews and questionnaires. Results showed that almost $53 \%$ of students stated that they liked the color of the lunch menu, whereas as many as $67 \%$ of students agreed with the aroma generated from the delicious lunch menu and could stimulate appetite. As many as $65 \%$ of students agreed that the food menu served had a good taste, meanwhile flatness level Grade VI students are higher than grade IV and V students, and 62\% of students often do not spend

\section{METHOD}

Research was conducted from August to September 2017 in SD Islam Tompokersan, Lumajang. Research method is employed by quantitative descriptive using cross sectional test. The subject of research is students of grade IV, V and
VI to assess the object of research. Collecting data was obtained by interviews, questionnaires and observations. The other information are also gathered including school profiles, operational management, sanitary and hygiene of school.

\section{RESULTS AND DISCUSSION}

\section{Profiles of SD Islam Tompokersan Lumajang}

SD Islam Tompokersan Lumajang is a private Islamic school that was established in 1963 under the auspices of the foundation of social education under Islam Nurul Mashithah sdsislamtompokersan-lmj, 2012). SD Islam Tompokersan Lumajang implemented full day school in their learning system. SD Islam Tompokersan Lumajang have basic facilities to support learning activities such as classrooms, laboratories, prayer room, dining room. The number of students were totaled 601 children, consisted of grade 1 to grade 6 . The facilities of SD Islam Tompokersan Lumajang can be seen in Table 1.

Table 1. Facilities of SD Islam Tompokersan Lumajang

\begin{tabular}{llccc}
\hline \multirow{2}{*}{ No. } & \multicolumn{1}{c}{ name space } & \multicolumn{2}{c}{ ownership } & \multirow{2}{*}{ amount } \\
\cline { 3 - 4 } & & Yes & No & \\
\hline 1. & Material storage space & $\sqrt{n}$ & - & 1 \\
\hline 2. & Kitchen space & $\sqrt{ }$ & - & 1 \\
\hline 3. & The dining room & $\sqrt{ }$ & - & 2 \\
\hline 4. & The laundry room materials and tools & $\sqrt{ }$ & - & 1 \\
\hline 5. & Bathrooms employee & $\sqrt{ }$ & - & 1 \\
\hline
\end{tabular}


acted as an energy substitution by deriving it from carbohydrate depleted as a result of physical activity of children.

Organizing step in operational management of lunch menu at SD Islam Tompokersan Lumajang is managed directly by the foundation board. They took a role as responsible as well as supervisory activities in school lunches. The school principal has duties as supervisor by asking at report either in written or oral. Monitoring carried out by principals on student lunch activities aims to ensure that the food served is safe to be consumed by students and meet the nutritional needs of keeping their activities acted upon excited in learning activities for students in the school. The executive work is done by helpers executor, in which their main duties are about assisting food processing activities and is responsible for the equipment and cleanliness of the kitchen. The role of this activity got also involved the school's board, such as vices principal in curriculum, student, staffing, and infrastructure.

The implementation stage of student's lunch menu in SD Islam Tompokersan Lumajang is consisted of procurement of foodstuffs, material receiving groceries, food processing, storage of foodstuffs, serving, distribution and presentation of food. Procurement of foodstuffs is done freshly from food market and made on a daily basis to minimize the use of food ingredients. Acceptance of groceries is merely carried out through the examination to ensure the suitability of foodstuffs with the food menu. Preparations include preparation of appliance and utensil, menu that will be processed, and groceries laundering activities. Processing techniques used in the implementation stage are involved of frying, sautéing, boiling and steaming. The food portion is estimated carefully to minimize excess of foodstuffs. The presentation is undertaked by placing food on the dining table, completed by a side dish and vegetable served in accordance with a predetermined portion.

\section{Acceptance Level of Visual of Lunch Menu}

Acceptance level of visual of lunch menu among students at SD Islam Tompokersan Lumajang is shown on Figure 1 below.

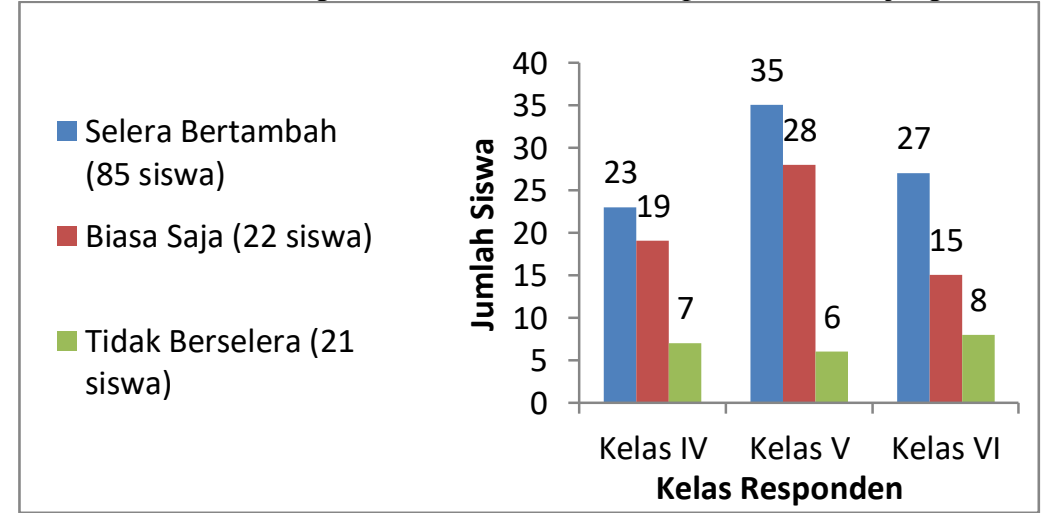

Figure 1. Acceptance Levels of Visual of Lunch Menu among Students at SD Islam Tompokersan Lumajang 
indicates that the color of the food served on the lunch menu consisting of a wide range of colors to stimulate the senses of students that can cause appetite
The results showed that $53 \%$ of elementary school color of the food served to increase appetite students. This

\section{Acceptance Level of Aroma of Lunch Menu}

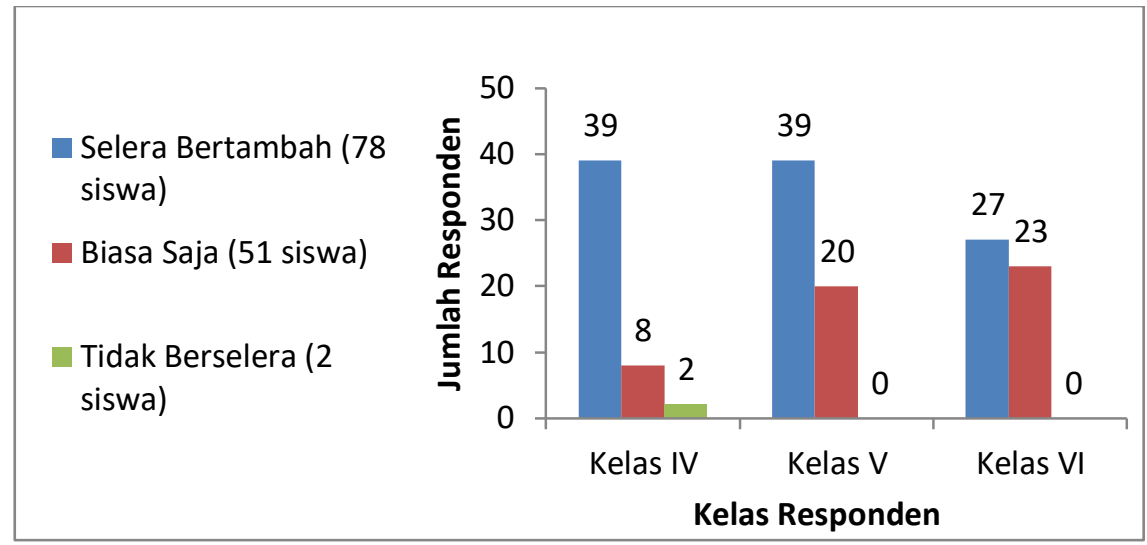

Figure 2. Acceptance Levels of Aroma of Lunch Menu among Students at SD Islam Tompokersan Lumajang

The results showed that $67 \%$ of students stated that the food served at lunch in SD Islam Tompokersan Lumajang that the taste was delicious. Aroma of steamed food generated from the food before it is served first warmed. Aroma may arise from steaming heated-food. Aroma arising from the processing can cause hunger so as to increase the appetite of students to eat.

\section{Acceptance Level of Taste of Lunch Menu}



Figure 3. Acceptance Levels of Taste of Lunch Menu among Students at SD Islam Tompokersan Lumajang

According to the results of the analysis of acceptance levels of taste the food served showed about $65 \%$ of students answered agree if the food served has a delicious flavor. The taste of food is one of the factors that affect the acceptability of the food served. According to Mukhtar (2004) determinants of food flavors influenced by the smell of food, seasoning and flavoring ingredients added to food as well as the temperature of the food when the food is served. The students tasted the smell of food, ingredients and temperature of the food served in lunch menu has the appropriate mix so that it produce a delicious taste of food resulted from food processing of lunch menu in SD Islam Tompokersan Lumajang has a good flavor. 


\section{Analysis of Boredom on Lunch Menu}

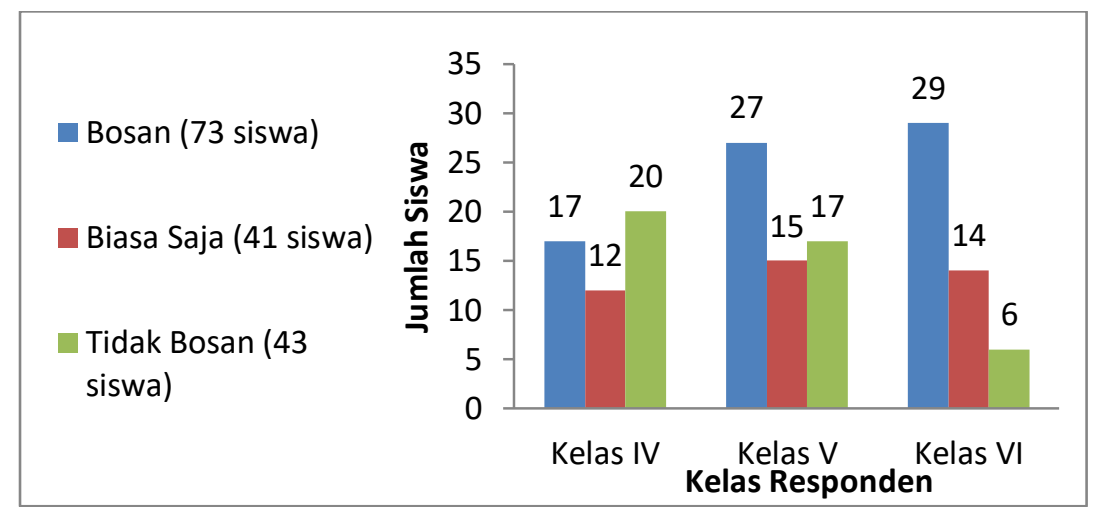

Figure 4. Boredom level on Lunch Menu in SD Islam Tompokersan Lumajang

According to the analysis, the level of boredom on lunch menu in SD Islam Tompokersan Lumajang showed as much as $53 \%$ of students feel boring with the food menu remainder answered bored and amounted to $47 \%$ of students answered not bored with the food served. According Moehyi (1992) in Paruhita, et al (2014) boredom can arise if the food served is less varied.
The menu is repeated with the distance is too close and takes place in a long time cause less bervariasi.Menu menu that is less varied makes students familiar with the kind of menu that is served. The factors that lead to boredom in students.

\section{Analysis of Student's Consumption Level}

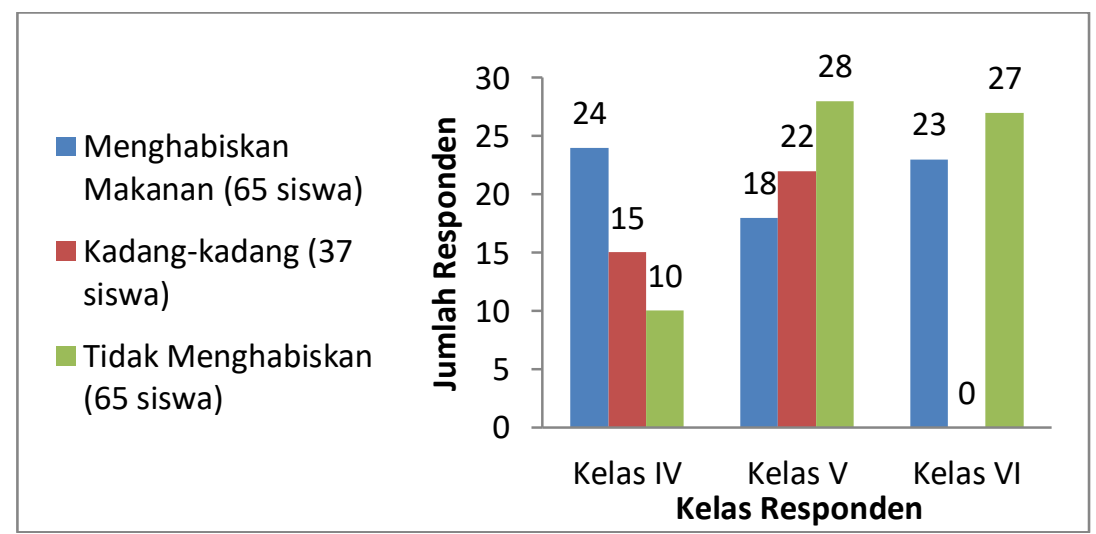

Figure 5. Student's Consumption Level on Lunch Menu in SD Islam Tompokersan Lumajang

According to Gregoire \& Spears (2007) in Bellatrix (2011) acceptability of food can be measured by weighing the rest of the food on the plate. Result shows that the level of student's consumption in SD Islam Tompokersan Lumajang as much as $62 \%$ of students answered not always spend lunch and as much as $38 \%$ of students always was wasting their lunch.

Students who do not spend on food can be caused because students feel bored with the food menu. The tedium of students can be seen from the results of research. Eating habits also influence students to not spend on food.

\section{CONCLUSION}

The implementation Process of lunch menu in SD Islam Tompokersan Lumajang has applied steps of planning, organizing, implementation and monitoring. Planning physical facilities such as indoor and processing equipment is available, although there are still shortcomings. The lunch menu is less varied and calculating calorie needs of students on the food served is not too much attention. Organizing consists of the responsible group, a group of manager, implementation group, and group executive helpers. Operational of lunch menu in SD Islam Tompokersan Lumajang include procurement of materials, preparation of materials, processing, storage, distribution and presentation. Implementation activities running properly and there are no significant obstacles.

Receptivity of students to the color of the food served showed a percentage of $53 \%$. The color of the food served 
to arouse the appetite of students. Receptivity of students to the smell of food showed a percentage of $67 \%$. The aroma of the food served at lunch that can stimulate the appetite of students. Acceptance of students to the taste of the food served showed a percentage of $53 \%$. The taste of the food served has a delicious flavor that can increase appetite students. The level of student boredom on the food menu shows the percentage of $53 \%$. The highest level of boredom there in Class VI. The consumption level students showed a percentage of $60 \%$. Students who often do not spend the lunch menu because students feel bored with the food menu.

\section{REFERENCES}

[1] Bellatrix N. 2011. Analysis of Availability of and power Accept Food in Schools Against Substance Nutritional Adequacy Levels Students SD Marsudirini Parung, Bogor. Thesis (Online) (http://repository.ipb.ac.id/jspui/bitstream/12345 6789/52367/1/I11nbp.pdf). Accessed 12 April 2017

[2] Moehyi S. 1992. Implementation Institutions and Services Food Boga.Jakarta: Bhratara.

[3] Paruhita, et al. 2014 Overview of Quality Time Food and Nutrition Food Delivered Installation General Hospital Dr. Kariadi Semarang. Journal of Nutrition. (On line), (http://ejournal.undip.ac.id/index.php/actanutrica /article/view/7794) Accessed on 13 November 2017.

[4] Peraturan Menteri Kesehatan Republik Indonesia Nomor 75 Tahun 2013 tentang Angka Kecukupan Gizi yang Dianjurkan Bagi Bangsa Indonesia. (Online), http://gizi.depkes.go.id/download/Kebijakan\%20 Gizi/Tabel\%20AKG.pdf diakses pada tanggal 12 Mei 2017.

[5] SD Islam Tompokersan Lumajang. 2012. Profil Sekolah. (Online). (http://sdsislamtompokersanlmj.sch-id.net/profil.html). Diakses 12 Juni 2017. 